\title{
ВІДГОДІВЕЛЬНІ ЯКОСТІ ТА МЯСНА ПРОДУКТИВНІСТЬ ОВЕЦЬ ЦИГАЙСЬКОӤ ПОРОДИ І ПОМІСЕЙ 3 РІЗНОЮ ЧАСТКОЮ СПАДКОВОСТІ ОДЕСЬКОГО ТИПУ АСКАНІЙСЬКОЇ М'ЯСО-ВОВНОВОЇ ПОРОДИ
}

\author{
В. Чігірьов, І. Різничук, С. Гурко, К. Мажиловська \\ Одеський державний аграрний університет
}

Досліджували відгодівельні якості та м'ясну продуктивність чистопородних валашків цигайської породи та помісних від різних варіантів схрещувань з одеським типом асканійської м'ясо - вовнової породи: витрати на 1 кг приросту живої маси поживних речовин (кормових одиниць, перетравного протеїну); забійні якості, морфологічний склад туш; м'ясні якості; співвідношення внутрішніх органів.

Ключові слова: жива маса, відгодівельні якості, забійні якості, маса туші, забійний вихід, морфологічний склад туш, м'ясні якості, внутрішні органи.

Постановка проблеми. На Одещині (зокрема Південні райони) галузь вівчарство завжди була традиційною. Селекція овець цигайської породи, яка $\epsilon$ районованою методом чистопородного розведення не вплинула до суттєвого підвищення продуктивності тварин, зокрема м'ясної та покращення iї якості. Тому виникла потреба пошуку більш ефективних заходів, які $б$ забезпечили створення популяції нових генетичних комплексів та зміну іiі структури. Підвищення попиту на високоякісну ягнятину, молоду баранину й овече молоко в другій половині минулого століття поставило перед вченими й спеціалістами 3 вівчарства завдання щодо зміни напряму селекції і спеціалізації галузі. Внаслідок багаторічної селекційної роботи було створено нову асканійську м'ясо-вовнову породу овець із кросбредною вовною, в структурі якої п'ять зональних типів, у тому числі - одеський тип.

Аналіз останніх досліджень і публікацій. Головною проблемо вівчарства залишається висока собівартість продукції вівчарства i, як наслідок, неприйнятна ринком ціна іiї реалізації.

Основними породами на півдні України є асканійська тонкорунна, асканійська м'ясововнова 3 кросбредною вовною, асканійська каракульська та цигайська. Найчисельніша 3 них цигайська 192 тис., або 51,9\%.

Подальший розвиток вівчарства можливо забезпечити шляхом його інтенсифікації, промислового виробництва ягнятини та молодої баранини і формуванням нових напрямів продуктивності - виробництво вовни кросбредного типу та кросбредної вовни, м'ясного та молочного [3].

Мета племінної роботи з вівцями цигайської породи - постійне збільшення виробництва високоякісної вовни, ягнятини, баранини, молока та овчин, при збереженні біологічних особливостей, притаманних цим тваринам, зокрема підвищення генетичного потенціалу стада за рівнем м'ясної продуктивності, вираженістю м'ясних форм, вовновими якостями та плодючістю шляхом створення нових ліній і споріднених груп [1].

При порушенні питання про використання інтенсивних типів овець асканійської селекції особливе місце займає також обгрунтування можливості підвищення м'ясної продуктивності i поліпшення якості м'яса селекційним шляхом.

Найбільш ефективним методом підвищення м'ясної продуктивності і покращення іï якості $\epsilon$ залучення до виробництва новоствореної породи якою $є$ асканійська м'ясо-вовнова порода овець 3 кросбредною вовною, та зокрема ії одеський тип [4].

За живою масою вівці всіх статевих і вікових груп значно перевершують аналогічні показники вихідної породи. Основна маса тварин має міцну конституцію, добре розвинене вим'я, молочність - 135-150 кг за підсисний період. Ягнят відлучають у віці 120 днів, після чого всіх маток доять протягом 30-40 днів, одержуючи додатково по 20-25 кг товарного молока на кожну матку, яке переробляють на бринзу, що користується великим попитом у місцевого населення.

Дослідження показали, що ягнята вже в 9-12-місячному віці досягають 40-45 кг, а тушки важать 18-21 кг. Характерно, що ягнятина в цьому віці майже не має специфічного запаху 
баранини, тому що в її складі ще мало гірсинової кислоти, і страви, приготовані з такого м’яса, вдаються особливо смачними [5].

До основних кількісних селекційних ознак овець напівтонкорунних порід включені такі як:величина, жива маса і вгодованість овець, а також приріст живої маси ягнят за 20 та 100 днів від народження [2].

Мета роботи полягала у визначенні можливості поліпшення генетичного потенціалу м'ясної продуктивності та якості м'яса ягнятини (молодої баранини) місцевої популяції цигайських овець методом схрещування з баранами одеського типу асканійської м'ясо - вовнової породи з кросбредною вовною.

Матеріал і методи досліджень. Науково-виробничий експеримент проведено в умовах племінного заводу з розведення овець цигайської породи СВК «Нива» Саратського району Одеської області. Відгодівельні якості і м'ясна продуктивність вивчали у валашків цигайської породи (I група) та помісних з різною часткою спадковості: $3 / 4$ одеський тип + $1 / 4$ цигайська порода (II група); 1/4 одеський тип + 3/4 цигайська порода (III група).

М'ясну продуктивність чистопородних і помісних ягнят вивчали шляхом проведення контрольної відгодівлі валашків на протязі 60 днів,( з 6- до 8-місячного віку) і їх забою у 8 місячному віці. Для забою було відібрано по 5 валашків, типових для своїх груп за живою масою і тілобудовою.

При забої вивчали перед забійну масу, масу туші, забійну масу, забійний вихід, морфологічний і сортовий склад туш, а також масу паренхіматозних органів і кишковошлункового тракту. Площу «м'язового вічка» визначали шляхом вимірювання довжини і ширини поперечного зрізу найдовшого м'язу спини, обчислення площі і множенням на коефіцієнт 0,8 .

Ці дослідження проведені за відповідними методиками Інституту тваринництва степових районів ім. М.Ф. Іванова «Асканія Нова» - Національного Наукового селекційно-генетичного центру з вівчарства.

Результати досліджень. При аналізі відгодівельних якостей перш за все звертається увага на ефективність використання корму. Ця важлива селекційна ознака хоча прямо не впливає на м'ясну продуктивність овець, проте тісно пов'язана 3 нею і має економічне значення. Для товарного вівчарства не без різниці з якими витратами отриманий той чи інший продукт.

Поліпшення ефективності використання корму на приріст маси тіла сприяє перш за все підвищенню засвоюваності поживних речовин корму, а взагалі й позитивно впливає окремі компоненти продуктивності: м'ясо, вовну, молоко.

У наших дослідженнях проведена оцінка відгодівельних якостей чистопородних валашків цигайської породи та їх помісей з різним ступенем кровності за цигайською породою та одеським типом асканійської м'ясо - вовнової породи (таблиця 1).

Таблиця 1.Відгодівельні якості ягнят (n=30)

\begin{tabular}{|c|c|c|c|c|c|c|c|}
\hline $\begin{array}{c}\text { Група, Порода, } \\
\text { породність }\end{array}$ & \multicolumn{2}{|c|}{$\begin{array}{c}\text { Жива маса,кг } \\
\qquad \overline{\mathrm{X}} \pm \mathbf{S} \overline{\mathbf{x}}\end{array}$} & \multirow{2}{*}{ 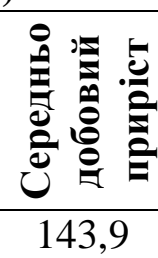 } & \multicolumn{2}{|c|}{ Спожито } & \multicolumn{2}{|c|}{$\begin{array}{c}\text { Витрати на 1кг } \\
\text { приросту } \\
\text { поживних } \\
\text { речовин }\end{array}$} \\
\hline І-ЦГ & $26,88 \pm 0,61$ & $33,35 \pm 0,54$ & & 49,5 & 4,92 & 7,64 & $\overline{759,0}$ \\
\hline II-3/4OT+1/4ЦГ & $28,60 \pm 0,33$ & $35,88 \pm 0,67$ & 161,7 & 49,5 & 4,92 & 6,80 & 676,3 \\
\hline III-1/4OT+3/4ЦГ & $30,78 \pm 0,46$ & $38,53 \pm 0,44$ & 172,2 & 49,5 & 4,92 & 6,39 & 634,8 \\
\hline
\end{tabular}

При постановці на відгодівлю помісні валашки II групи на 1,72 кг або на 6,3\% (P>0,95), а помісні валашки III групи на 14,5 \% (P>0,999) за живою масою переважали чистопородних. Після закінчення відгодівлі різниця за показником живої маси валашків контрольної та дослідних груп складала 7,6-15,5 \% (Р>0,95; Р>0,999) на користь останніх.

Серед помісних валашків наприкінці відгодівлі більшу живу масу мали тварини III групи. Вони на 2,65 кг або на 7,4\% (Р>0,99) переважали однолітків II групи.

Помісний молодняк за період відгодівлі мав більш високу енергію росту ніж чистопорідний. За середньодобовим приростом живої маси помісі переважали чистопородних ровесників на 12,4 $-19,7 \%$. 
Вони мали дещо більш високі показники відносної швидкості росту $(22,4$ - 22,6 \% проти $21,5 \%)$.

Помісні валашки більш ефективно використовували поживні речовини корму. У порівнянні з чистопородними, помісні тварини II і III дослідних груп використовували менше кормових одиниць і перетравного протеїну на 1 кг приросту живої маси (відповідно на 11,0 - 16,4 \% і 11,0 $-16,5 \%)$.

Серед помісних валашків більш ефективно трансформували корм у продукцію $1 / 4$ - кровні за одеським внутрішньо породним типом.

Результати контрольного забою показали, що кращими забійними якостями характеризувалися помісі дослідних груп (таблиця 2).

Таблиця 2.3абійні якості валашків $(\mathbf{n = 1 5})$

\begin{tabular}{|l|c|c|c|}
\hline \multirow{2}{*}{\multicolumn{1}{|c|}{ Показники }} & \multicolumn{3}{|c|}{ Група. Порода, породність } \\
\cline { 2 - 4 } & $\mathbf{I - Ц \Gamma}$ & $\mathbf{I I - 3 / 4 0 T + 1 / 4 Ц \Gamma}$ & $\mathbf{I I I - 1 / 4 0 T + 3 / 4 Ц \Gamma ~}$ \\
\cline { 2 - 4 } & $\overline{\mathrm{X}} \pm \mathbf{S} \overline{\mathbf{x}}$ & $\overline{\mathrm{X}} \pm \mathbf{S} \overline{\mathbf{x}}$ & $\overline{\mathrm{X}} \pm \mathbf{S} \overline{\mathbf{x}}$ \\
\hline Передзабійна жива маса, кГ & $31,90 \pm 0,62$ & $34,31 \pm 0,5$ & $36,80 \pm 0,91$ \\
\hline Забійна маса, кг & $14,89 \pm 0,27$ & $16,23 \pm 0,43$ & $18,19 \pm 0,66$ \\
\hline Маса туші, кг & $14,42 \pm 0,26$ & $15,70 \pm 0,42$ & $17,60 \pm 0,65$ \\
\hline Маса внутрішнього жиру, кг & $0,472 \pm 0,019$ & $0,526 \pm 0,018$ & $0,585 \pm 0,014$ \\
\hline Забійних вихід, \% & $46,71 \pm 0,80$ & $47,33 \pm 0,49$ & $49,41 \pm 1,28$ \\
\hline
\end{tabular}

Помісі дослідних груп переважали чистопородних валашків за перед забійною масою, масою туші і забійному виходу. Так, за перед забійною масою різниця на користь помісних овець склала: у II групи - 7,5 \% (P>0,95), III групи - 15,4 \% (P>0,99); за забійною масою в II групі - 9,0 $\%(\mathrm{P}>0,95)$, у III групі - 22,2 \% (P>0,99).

За масою туші помісі переважали чистопородних ровесників. Туші помісей II групи виявилися важчим на 8,9 \% ( $>>0,95)$, а III групи на 22,1\% (P>0,99), ніж туші чистопородного молодняку. Туші помісних ягнят характеризувалися високим забійним виходом.

Різниця між групами, що зрівнюються за забійним виходом складає: між I і II - 0,62 абсолютних відсотка на користь II групи; між I і III - 2,7 абсолютних відсотка на користь III групи.

За масою внутрішнього жиру помісі III групи на 23,9 \% переважали чистопородних цигайських ровесників, і на 11,2 \% помісний молодняк II групи.

Розділення баранячих туш проводилось на 6 відрубів, що поділяються на 2 торгівельні сорти: до першого належить тазо-стегновий, поперековий, спинно-лопатковий відруби; а до другого - заріз передпліччя та задня гомілка.

У цілому, туші валашків усіх груп, що досліджувалися відрізнялися добрим товарним виглядом, були покриті рівномірним жировим прошарком.

Дані наведені в таблиці 3 показують, що більш високим виходом відрубів першого сорту відрізнялися туші ягнят II і III груп, - 91,3 і 91,68 \%, що відповідно, на 0,45 і 0,83 абсолютних процента вище у порівнянні з I групою.

Таблиця 3.Сортовий склад туш

\begin{tabular}{|c|c|c|c|}
\hline \multirow{2}{*}{ Показники } & \multicolumn{3}{|c|}{ Група. Порода, породність } \\
\hline & ІІЦГ & II-3/4OT+1/4ЦГ & III-1/4OT+3/4ЦГ \\
\hline Маса туші, кг & $14,42 \pm 0,26$ & $15,70 \pm 0,42$ & $17,60 \pm 0,65$ \\
\hline Сортовий склад, \% & & & \\
\hline I & 90,85 & 91,30 & 91,68 \\
\hline II & 9,15 & 8,70 & 8,32 \\
\hline
\end{tabular}

Відповідно, вихід відрубів II сорту був більшим 3 туш чистопородного цигайського молодняку.

Співвідношення в тушах м'язової, жирової, сполучної і кісткової тканини встановлювалося на підставі вивчення їх морфологічного складу. 
У наших дослідженнях для вивчення морфологічного складу було проведено обвалювання туш валашків чистопородних цигайських і помісних, з різними частками кровності цигайської породи і одеського внутрішньо породного типу асканійської м'ясо-вовнової породи. (таблиця 4).

Таблиця 4.Морфологічний склад туш

\begin{tabular}{|c|c|c|c|}
\hline \multirow{2}{*}{ Показники } & \multicolumn{3}{|c|}{ Група. Порода, породність } \\
\hline & І-ЦГ & II-3/4OT+1/4ЦГ & III-1/4OT+3/4ЦГ \\
\hline Маса туші, кг & $14,42 \pm 0,26$ & $15,70 \pm 0,42$ & $17,60 \pm 0,65$ \\
\hline $\begin{array}{l}\text { Вміст у туші: } \\
\text { М'якоті, кг } \\
\%\end{array}$ & $\begin{array}{c}10,84 \pm 0,27 \\
75,2\end{array}$ & $\begin{array}{l}12,04 \pm 0,40 \\
76,7\end{array}$ & $\begin{array}{l}13,66 \pm 0,54 \\
77,6\end{array}$ \\
\hline $\begin{array}{l}\text { Кісток, кг } \\
\%\end{array}$ & $\begin{array}{c}3,58 \pm 0,02 \\
24,8\end{array}$ & $\begin{array}{c}3,66 \pm 0,03 \\
23,3\end{array}$ & $\begin{array}{l}3,94 \pm 0,11 \\
22,4\end{array}$ \\
\hline $\begin{array}{l}\text { На } 1 \text { кг перед забійної } \\
\text { живої маси, г }\end{array}$ & 339,8 & 351,0 & 371,2 \\
\hline Коефіцієнт м'ясності & 3,03 & 3,29 & 3,47 \\
\hline
\end{tabular}

Дані наведені у таблиці свідчать, що в тушах помісних валашків було більше м'якоті і менше кісток. Так, м'якоті в тушах помісних валашків II групи було 76,7 \%, III - 77,6 \%, у той час, як у цигайських - 75,2 \%. Молодняк II і III дослідних груп за вмістом м'яса в туші переважав контрольний I групи на 11,4% (Р>0,95), і на 26,0% (Р>0,99), відповідно.

При оцінці м'ясної продуктивності необхідно враховувати і такий показник, як коефіцієнт м'ясності. За результатами наших досліджень коефіцієнт м'ясності був вище у помісей обох груп: II - 3,28; III - 3,47, у той час як у тушах цигайських ягнят - 3,03.

Одним 3 показників м'ясних якостей овець $є$ площа «м'язового вічка».

У наших дослідах нащадки, 3 різними частками кровності за цигайською породою $\mathrm{i}$ одеським типом відрізнялися більшою площею «м'язового вічка» (таблиця 5).

Таблиця 5.М'ясні якості овець

\begin{tabular}{|c|c|c|c|c|}
\hline $\begin{array}{c}\text { Група. Порода, } \\
\text { породність }\end{array}$ & $\begin{array}{c}\text { Вихід } \\
\text { м'якоті } \\
\text { туші,\% }\end{array}$ & $\begin{array}{c}\text { Маса } \\
\text { найдовшого } \\
\text { м'яза спини, г }\end{array}$ & $\begin{array}{c}\text { Площа } \\
\text { «мускульного } \\
\text { вічка», см }\end{array}$ & $\begin{array}{c}\text { Довжина } \\
\text { туші, см }\end{array}$ \\
\hline І-ЦГ & 75,2 & $934 \pm 53,2$ & $12,91 \pm 0,57$ & $76,7 \pm 0,96$ \\
\hline II-3/4ОТ+1/4ЦГ & 76,7 & $1122 \pm 63,4$ & $14,83 \pm 0,60$ & $79,2 \pm 0,98$ \\
\hline III-1/4ОТ+3/4ЦГ & 77,6 & $1208 \pm 39,3$ & $16,12 \pm 0,46$ & $81,5 \pm 0,88$ \\
\hline
\end{tabular}

Помісі II групи за площею «м'язового вічка» на 14,9 \% (P>0,95), а III групи - на 24,9 \% (P>0,99) переважали цигайських ровесників.

У свою чергу, площа «м’язового вічка» в тушах помісей III групи на 8,7\% (P>0,95), більше цього показника помісей II групи.

Помісні валашки II і III груп характеризувалися кращим розвитком найдовшого м'язу спини. Так, за масою найдовшої м'язової тканини помісі II групи переважали чистопородних цигайських ровесників на 20,1 \% (P>0,95), а III - на 29,3\% (P>0,99).

3 даних таблиці також видно що за довжиною тушки різниця на користь помісей II групи склала $3,3 \%$, а помісей III групи - 6,3 \%. Таким чином кращими м'ясними якостями характеризувалися туші помісних валашків, а серед них туші молодняку III групи, що ми пов'язуємо з ефектом гетерозису у помісних тварин.

Встановлена породна різниця в розвитку окремих відділів шлунку чистопородних i помісних овець. Всі відділи шлунку краще розвинені у помісних нащадків. Так помісі II групи переважали нащадків материнської породи за масою рубця (678 г і 575 г) - на 17,9 \%; сичуга (187 г і 180 г) - на 3,9 \%; сітки (148 г і 117 г) - на 26,4 \%, і книжки (139 г і 123 г) - на 13,0 \%. В той час як, валашки III групи відповідно, на 4,5\%, 1,7\%, 8,5\% і 19,5\%.

Помісний молодняк характеризується також більшими об'ємами рубця (7340 - 7733 мл, проти 7166 мл); сичуга (969 - 1165 мл, проти 927мл); книжки (68 - 75 мл, проти 66 мл); сітки (532 - 537 мл, проти 530 мл). 
Використання в селекції овець визначення ступеня розвитку рубця дозволяє відбирати високопродуктивних тварин, які здатні максимально використовувати об'ємисті корми 3 відповідною трансформаціє поживних речовин в продукцію тваринництва та сировину.

Дані довжини і маси кишечнику овець наведені в таблиці 6.

Таблиця 6. Довжина і маса кишечнику чистопородних і помісних ягнят

\begin{tabular}{|c|c|c|c|c|c|}
\hline \multirow{2}{*}{$\begin{array}{c}\text { Група. Порода, } \\
\text { породність }\end{array}$} & \multicolumn{3}{|c|}{ Довжина кишечнику,м } & \multicolumn{2}{c|}{ Маса кишечнику, $\mathbf{~} \mathbf{\text { Х }} \pm \mathbf{\mathbf { x }}$} \\
\cline { 2 - 5 } & тонкого & товстого & загальна & тонкого & товстого \\
\hline I-ЦГ & $24,56 \pm 0,46$ & $5,51 \pm 0,22$ & $30,07 \pm 0,3$ & 648 & 478 \\
\hline II-3/4ОТ $+1 / 4 Ц Г$ & $27,11 \pm 0,17$ & $6,53 \pm 0,12$ & $33,64 \pm 0,23$ & 706 & 583 \\
\hline III-1/4ОТ+3/4ЦГ & $30,27 \pm 0,47$ & $6,70 \pm 0,21$ & $36,97 \pm 0,51$ & 756 & 603 \\
\hline
\end{tabular}

За довжиною кишечнику спостерігається перевага помісей обох груп, так загальна його довжина у валашків II групи, на 11,9\% ( $>>0,99)$, а III - на 22,9 \% (P>0,999) більше ніж у цигайського молодняку. 3 даних таблиці також видно, що масою кишечнику помісі II групи на 14,5 \%, а III групи на 20,6 \% перевищують чистопородний молодняк I групи.

\section{Висновки.}

1. Помісний молодняк за період відгодівлі мав більш високу енергію росту ніж чистопородний. За середньодобовим приростом живої маси помісі переважали чистопородних ровесників на 12,4 - 19,7 \%. Помісні валашки більш ефективно використовували поживні речовини корму.

2. Помісі обох дослідних груп переважали чистопородних валашків за перед забійною масою, масою туші і забійному виходу. Туші помісей II групи виявились важчими на 8,9 \%, a III групи на 22,1%. Туші помісних ягнят характеризувалися високим забійним виходом (47,3 -49,4 $\%)$.

3. Більш високим виходом відрубів I сорту відрізняються туші ягнят II і III груп - 91,30 і 91,68 \%, що відповідно на 0,45 і 0,83 абсолютних процента вище у порівнянні з I групою.

4. В тушах помісних валашків було більше м'якоті і менше кісток; м'якоті в тушах помісних валашків II групи було 76,7 \%, III - 77,6 \%, у той час як у I групи 75,2 \%.

5. Кращими м'ясними якостями характеризувалися туші помісних валашків, а серед них туші молодняку III групи (1/4 ОТ + 3/4 ЦГ).

6. Встановлена породна різниця в розвитку окремих відділах шлунку, довжини і маси кишечнику у чистопородних і помісних овець; за цими інтер'єрними показниками перевага спостерігається у помісних валашків з різним ступенем кровності одеського зонального типу.

Перспектива подальших досліджень. В майбутньому буде проведена оцінка результативності поєднань порід і типів у наступних поколіннях.

\section{Список використаних джерел}

1. Вівчарство України. Наукове видання / В.М. Іовенко, П.І. Польська, О.Г. Антонець, В.М. Бова, Т.Г. Болотова, В.І. Вороненко та ін. - Київ, Аграрна наука, 2006. -614 С.

2. «Інструкція з бонітування овець». Інструкція з ведення племінного обліку у вівчарстві і козівництві. Київ - 2003. - 154 С.

3. Наукові засади розвитку вівчарства південного регіону України / Ю. В. Вдовиченко, Н. А. Кудрик, П. Г. Жарук, Л. В. Жарук // Вівчарство та козівництво. - 2017. - Вип. 2. - С. 3-23.

4. Чігірьов В.О., Чепур В.К. Оцінка основних селекційних ознак продуктивності овець одеського внутрішньо породного типу асканійської м'ясо - вовнової породи. /Матеріали VII міжнародної науково-практичної конференції. Зоотехнічна наука: історія, проблеми, перспективи.-Камянець-Подільський, 2017. - 68-71 С.

5. https://propozitsiya.com/ua/myaso-vovnove-vivcharstvo-odeshchini. 


\section{ОТКОРМОЧНЫЕ КАЧЕСТВА И МЯСНАЯ ПРОДУКТИВНОСТЬ ОВЕЦ ЦИГАЙСКОЙ ПОРОДЫ И ПОМИСЕЙ С РАЗЛИЧНОЙ ЧАСТЬЮ НАСЛЕДСТВЕННОСТИ ОДЕССКОГО ТИПА АСКАНИЙСКОЙ МЯСО-ШЕРСТНОЙ ПОРОДЫ}

Чигирёв В., Ризничук И., Гурко Е., Мажиловская К.

Исследовали откормочные качества и мясную продуктивность чистопородных валушкив цигайской породы и помисных от различных вариантов скрещиваний с одесским типом аканийской мясо-шерстной породы::затраты на 1 кг прироста живой массы питательных веществ (кормовых единии, переваримого протеина); убойные кчества, морфологический состав туш; мясные качества; соотношение внутренних органов.

Ключевые слова: живая масса, откормочные качества, забойные качества, масса туши, убойный выход, морфологический состав туш, мясные качества, внутренние органы.

\section{FATTENING QUALITIES AND MEAT PRODUCTIVITY OF TIGAI BREED SHEEP AND BREEDS WITH DIFFERENT PART OF HERITAGE OF ODESSA TYPE OF ASKANIYA-ASKANIYA VYSK}

Chigiryov V., Riznychuk I., Gurko Ie., Mazhilovskaya K.

We studied the fattening qualities and meat productivity of purebred cornflower breeds and local from different variants of crosses with Odessa type of Askanian meat - wool breed: costs per $1 \mathrm{~kg}$ of live weight gain of nutrients (feed units, digestible protein); slaughter qualities, morphological composition of carcasses; meat qualities; the ratio of internal organs.

Key words: live weight, fattening qualities, slaughter qualities, carcass weight, slaughter yield, morphological composition of carcasses, meat qualities, internal organs. 